Mercator, Fortaleza, v. 16, e16019, 2017.

DOI: https://doi.org/10.4215/rm2017.e16019

ISSN: $1984-2201$

Copyright @ 2002, Universidade Federal do Ceará

\title{
THE SOCIAL-SPATIAL FORMATION OF THE SOUTHWEST OF PARANÁ
}

(a) Phd. in Geography, Federal University of Santa Catarina (UFSC). http://lattes.cnpq.br/3211775870553998

\section{(*) CORRESPONDING AUTHOR}

Address:-Rua Pernambuco, 1759, n.1759. Centro. CEP:85601-300, Francisco Beltrão (PR). Tel: (+55 46) 999002149

E-mail: carlos.casaril@gmail.com

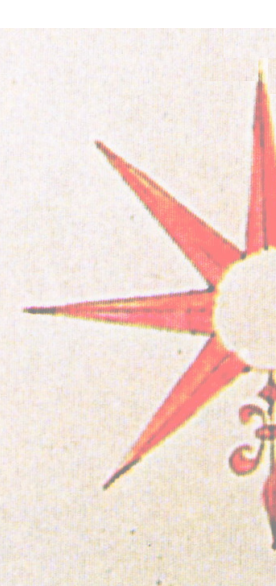

\begin{abstract}
The main objective of this work was to develop an analysis of the social-spatial formation of the Southwest of Paraná, presenting the genesis of the cities that make up the urban networks of Francisco Beltrão and Pato Branco. Various quantitative and qualitative methodological and operational procedures were used to carry out the research, including a bibliographic review, the collection of secondary data from several institutions, extensive documentary research in regional newspapers and bibliographies dealing with the theme. As a procedure, this work uses the category of Social-Spatial Formation. Therefore, it understands its evolution, its current situation, its historical change and its relations as a concrete-historical, geographically localized reality. This category is linked to the perspective of historical urban geography, as it seeks to analyze the historical process to unveil the pillars of spatial organization / transformation that result from the unity of continuity and discontinuity. As a result of the research, the objectives of unveiling the social-spatial formation of the region and its genesis, evolution and current situation were reached by linking this perspective to the urban network.
\end{abstract}

Keywords: Urban historical geography; Urban Network; Urban centers; Francisco Beltrão; Pato.

\section{RESUMO/RESUMEN}

\section{FORMAÇÃO SÓCIO-ESPACIAL SUDOESTE PARANAENSE}

O objetivo principal foi desenvolver análise sobre a formação sócio-espacial do Sudoeste paranaense, apresentando a gênese das cidades que compõem a rede urbana de Francisco Beltrão e de Pato Branco. Utilizaram-se procedimentos metodológicos e operacionais tanto de caráter quantitativos como qualitativos, bem como revisão bibliográfica, coleta de dados secundários em diversas instituições, sem se esquecer de ampla pesquisa documental em jornais regionais e em bibliografias que trataram da temática. Ainda como procedimentos, utiliza-se neste trabalho a categoria de Formação Sócio-Espacial. Esta categoria vincula-se com a perspectiva da geografia histórica urbana, pois procura realizar uma análise do processo histórico, buscando desvelar os pilares da organização/transformação espacial que decorre da unidade da continuidade e da descontinuidade. Como resultados da pesquisa, atingiu-se os objetivos de desvelar a formação sócio-espacial da região e de sua gênese, evolução e situação atual vinculando a essa perspectiva a rede urbana.

Palavras-chave: Geografia histórica urbana; Rede Urbana; Centros Urbanos; Francisco Beltrão; Pato.

\section{LA FORMACIÓN SOCIAL-ESPACIAL DEL SUDOESTE DEL PARANÁ}

El objetivo principal de este trabajo fue desarrollar un análisis acerca de la formación socio-espacial del sudoeste de Paraná, presentando la génesis de las ciudades que conforman la red urbana de Francisco Beltrão y de Pato Branco. Se utilizaron algunos procedimientos metodológicos y operativos para realizar la investigación, tanto de carácter cuantitativo como cualitativo, así como revisión bibliográfica, colecta de datos secundarios en varias instituciones, sin olvidar una extensa investigación documental en periódicos y bibliografías regionales que trataban del tema. Sin embargo, como procedimientos, se utiliza en este trabajo la categoría de Formación Socio-espacial. Esta categoría está vinculada a la perspectiva de la geografía histórica urbana, debido trata de realizar un análisis del proceso histórico, buscando destapar los pilares de la transformación organización / espacio que se deriva de la unidad de la continuidad y de la discontinuidad. Como resultados de la investigación, se alcanzaron los objetivos de desvelar la formación socio-espacial de la región y su génesis, evolución y situación actual, vinculando a esta perspectiva la red urbana.

Palabras clave: Geografía histórica urbana; Red Urbana; Centros urbanos; Francisco Beltrão; Pato. 


\section{INTRODUCTION}

The main objective of this work was to develop an analysis of the social-spatial formation of the Southwest of Paraná, presenting the genesis of the cities that make up the urban networks of Francisco Beltrão and Pato Branco. It is understood that this formation was determinant for the settlement and, therefore, for the origin of the cities, which in turn will evidence the formation of the urban network.

It is justified due to the relative absence of studies on the theme of historical geography, using social-spatial formation as a category of analysis in the Southwest of Paraná.

Some quantitative and qualitative methodological and operational procedures were used to carry out the research, as well as desk-bound work like bibliographic reviews and secondary data collection in several institutions, such as the Brazilian Institute of Geography and Statistics (IBGE) and the Institute of Land, Cartography and Geology of Paraná (ITCG). Extensive documental research was done in regional newspapers and in bibliographies that dealt with the theme, always emphasizing the good development of the research. In addition, fieldwork, one of the geographer's main tools, was carried out in order to better understand the historical-geographical reality of these localities.

As another procedure, this work uses the category of Social-Spatial Formation (proposed by Milton Santos in 1977), which refers to the analysis of a society's concreteness. Therefore, it understands its evolution, its current situation, its historical change and its relations as a concrete-historical, geographically localized reality.

This category is linked to the perspective of historical urban geography, as it seeks to analyze the historical process to unveil the pillars of spatial organization / transformation that result from the unity of continuity and discontinuity. Thus, historical geography is fundamentally a geographical study of the past; essentially it is a geographical study, not a historical one.

The present work is divided into four parts, the first presents the introduction; next is the theoretical input, which seeks to present the analytical categories that are the perspectives for the development of the present work, such as social-spatial formation, the issue of the urban network and its analytical proposals, perusing authors considered a reference in urban geography and therefore essential to urban literature. As a result, this second part allows the reader a better understanding of the analysis as a whole. The third section begins with a discussion about the formation of the Southwest of Paraná and the colonization of the region in the first half of the twentieth century, which is fundamental for understanding the formation of the region. The fourth part examines the intensification of the settlement and the genesis of the cities of the urban network of Francisco Beltrão and Pato Branco, besides the final considerations and the respective references.

\section{THEORETICAL CONTRIBUTIONS}

The proposals of Walter Christaller (central place theory, 1933), August Lösch (general theory of location, 1940), etc., have become important manuals in the literature on networked cities. In Brazil, some researchers have shared this type of analysis, such as the analysts of the Brazilian Institute of Geography and Statistics (IBGE) and the pioneers in the studies Pierre Deffontaines and Aroldo Azevedo, added to the works of Pierre Monbeig (1943, 1952, 1954), Pedro Pinchas Geiger (1963), Roberto Lobato Corrêa (1967) etc., who analyzed the genesis and evolution of the urban network delineated between the 1940s and 1960s.

The insertion of the studies of the urban network in Brazil had its genesis in the publication of Deffontaines' article (1944 and 1945) "Como se constituiu no Brasil a rede das cidades", in the Boletim Geográfico (the Geographical Bulletin published by the National Council of Geography (CNG), through the IBGE). In this article, Deffontaines (1944, p.141) begins his discussion with some relevant questions, among them: "How was a region endowed with urban agglomerations? How were they born, where were they installed, why did they progress? How is an urban network 
created? [...]". These questions are directly related to the emergence and evolution of urban centers in a given region and, consequently, to the structuring of their respective networks, indicating, in their historical and geographical evolution, the possibility of recognizing several moments, revealing the processes of social-spatial change.

Deffontaines $(1944,1945)$ points to the state of the art of the Brazilian urban systems of the 1930s and 1940s, declaring that the Brazilian urban network was in its "infancy", marked by the expectation of growth and instability in the cities. For this author, the configuration of the network of cities in Brazil in this period was configured in a disaggregated formation with small nuclei and not in an articulated urban system. Other researchers in later studies state that there was no network of cities in Brazil at that time, since the concept of an urban network refers to a set of cities that are spatially and functionally articulated. We agree with the concept of urban network, also with the one pointed out by Deffontaines, who argued that the network of cities was being formed, in the words of the author, it was in its "infancy".

In 1956, during the Congress of the International Geographical Union (UGI), held in Rio de Janeiro, the theme of the urban network reappeared and from then on, several researchers carried out analyzes on the subject. The years following the Congress were marked by the strengthening of the exchange between French and Brazilian geographers, a partnership promoted since the founding of the University of São Paulo (USP) and the University of the Federal District (UDF), which involved professionals such as Pierre Deffontaines, Pierre Monbeig, Roger Bastide, etc. Michel Rochefort and Pierre George, members of Active Geography were also noteworthy.

It is worth mentioning that Rochefort guided the Working Group on Urban Geography of the CNG's Department of Geography, which resulted in the work "O Rio de Janeiro e sua região", coordinated by Lysia Bernardes (1964). In addition to the method of classification of urban networks, the work "Evolução da rede urbana brasileira" by Pedro Geiger (1963) was of great value, together with the publications edited by the CNG-IBGE, especially the "Esboço preliminar de divisão do Brasil em espaços homogêneos e espaços polarizados" (IBGE, 1967), and "Subsídios à regionalização" (IBGE, 1968). Thus, it is clear that during the 1956 UGI and during the 1960s urban studies (highlighting the urban networks) had an intense presence in Brazil.

From its introduction until the present the theme has undergone several phases of diffusion and / or realignment of the studies and confrontations from a theoretical-methodological point of view. Such advances can be understood from the vast bibliography highlighting the works of Deffontaines (1944, 1945 [originally published in 1938 in France]); Monbeig (1943); Rochefort (1961); Geiger (1963); Bernardes (1964); Corrêa (1967, 1988, 1989, 1997); Müller (1969); Santos (1979, 1993); Fresca (1990; 2000); IBGE (1972, 1987, 2000, 2008); IPEA (2002); IPARDES (2002); and Bessa (2007), etc., in which evaluations of geographic production about urban networks in Brazil were carried out, as well as theoretical and methodological propositions being produced for such studies.

The urban network is a "set of functionally articulated centers", which, in turn, reflects and conditions economic-social transformations (Corrêa, 1989, p.8). The important thing to understand is that in order to unveil a given urban network, the analysis of its genesis and dynamics becomes essential and must be sought in its historical process, attributing a social-spatial nature and dimension to the network that reflects and conditions the society that produced it. Thus, the urban network would be "[...] a social product, historically contextualized, whose crucial role is, through spatialized social interactions, to articulate the whole of society in a given portion of space, guaranteeing its existence and reproduction" (CORRÊA, 1997, p.93).

Since the urban network is a social-spatial dimension of society, it is verified that the processes of conception, appropriation and circulation of surplus value, often modified, since it is integrated with the territorial division of labor, are equally in constant change. This leads to the understanding that the "urban network is simultaneously a reflection of and a condition for the territorial division of labor" (CORRÊA, 1989, p. 48). 
This work sought to use the category of Social-Spatial Formation, proposed by Milton Santos (1977), to analyze the formation of Southwest Paraná, as well as the genesis and structuring of the network of the cities of Francisco Beltrão and Pato Branco. This category seeks to reveal historical and geographically localized formations, that is, social-spatial formations.

Social-spatial formation refers to the analysis of a society's concreteness (including its evolution, its current situation, its historical change and its relations), being a concrete-historical, geographically localized reality. Its explanatory basis is production, that is, labor, where man transforms space. Its study enables "[...] the apprehension of the individual as a scission of the whole, a moment of the whole, as well as the whole reproduced in one of its fractions [...] but always a specific knowledge, apprehended in a given moment of its evolution "(SANTOS, 1977, p.84). Thus, the first step in understanding the social-spatial formation of a given urban network would be to reach reality.

Social-spatial formations, as stages of a historical process, refer to the unequal development of societies, which, in turn, reveal basic data to clarify why countries, regions and, why not, cities differ from each other. This, however, means that the basis of spatial organization / transformation coexists in the clash between what is established and what is established as new, resulting in an unequal and combined space that results from the unity of continuity and discontinuity (SANTOS, 1985).

\section{COLONIZATION IN THE FIRST TWO QUARTERS OF THE TWENTIETH CENTURY}

The Southwest of Paraná was formed from one of the last areas occupied by the agricultural frontier in the State of Paraná. It has the peculiarity of being an area colonized by small farmers (settlers) from Rio Grande do Sul and Santa Catarina, descendants of German and Italian immigrants, who were engaged in polyculture. However, it can be said that this characteristic is contemporary, because it was only from the years 1940-50 that there was rapid colonization by the migrant settlers.

The Southwest originated from the Campos de Palmas region, since the present area of the Southwest Paraná mesoregion belonged to the territory of the municipality of Palmas, which was established in 1879. At this time, the territorial area of the State of Paraná extended to the Uruguay river, on the border with Rio Grande do Sul. There was no formally installed municipality in the current western region of Santa Catarina, which belonged, therefore, to the municipality of Palmas.

The social-spatial formation of Palmas was characterized by a natural vegetation of fields, in which a class of cattle ranchers developed. This economic-spatial dynamic was highlighted in the literature on urban networks, Corrêa (2006, p.284) mentions that one of the characteristics of this social-spatial formation consists of the "[...] drainage of rural land revenue by the city, due to the absenteeism of large landowners [...] ", another characteristic is the formation of an urban network with a lower density and a greater spacing of centers.

The settlement that would give rise to the city of Palmas originated around 1840, and in 1846 "... a track linked Palmas directly to Campos Gerais, the [river] Iguaçu flowed through the site of the present city of União da Vitória [...]" (BERNARDES, 1952, p. 436). The occupation of the countryside in Palmas increased in the twilight of the nineteenth century, through stimuli from the state government, plus the concessions of sesmarias that favored livestock activities.

Like Palmas, but more recently, was the case of the municipality of Clevelândia, which was also located in the Palmas countryside and was established on June 28, 1892, founded by cattle ranchers from Guarapuava. The installation of the municipality of Clevelândia occurred with the dismemberment of lands previously belonging to the municipality of Palmas.

Both Palmas and Clevelândia are part of a social formation that has large properties as its main characteristic, in its genesis the landlord class were dominant and livestock was for a long time only the only, the main activity. This was the characteristic of the first two quarters of the twentieth 
century. After this period, other activities began to emerge such as logging, with the industries of laminate, plywood, etc., as well as the modernization of agriculture with the introduction of mechanized crops.

During the first fifty years of the twentieth century, the colonization process intensified in the areas of closed forests that currently belong to the Southwest of Paraná. This, therefore, refers to the other social-spatial formation, based on commercial production, unlike the rural social-spatial formation, which is based on the latifundium. The urban network of social-spatial formation based on small-scale commercial production has a clearer hierarchy, with a balanced supply and demand of productive, commercial and service functions.

Another social-spatial formation, as well as another geographical combination, emerges in the colonization of the wooded areas of the Southwest. In this formation, something very similar occurred to the combination described by Cholley (1964) for the Canadian West, particularly for prairie areas. In this region, "a denser polyculture system developed, which cushioned the effects of agricultural crises and conditioned a more stratified settlement and social structure, better able to achieve equilibrium" (CHOLLEY, 1964, p. 142-143).

The geographic combinations that can be considered so that settlement in the Southwest of Paraná occurred based on small commercial production, are due to the fact that this region was covered by dense forests, with a wide extension of Araucaria forests (Araucaria angustifolia). Also, this region has a rather rugged relief, a limiting factor for the use and conservation of soils, which favors erosion and makes the use of machinery difficult, which in practice lacked greater and complex care with the creation of pastures, thus requiring a greater employment of labor, than in areas with fields of crops (MAACK, 2002).

Taking these combinations into consideration allowed the outline of multiple geographical determinations, so that in this region there has been a social-spatial formation of small commercial production.

Until 1938, there were only the villages of Chopim and Bom Retiro (present-day Pato Branco) and some villages in the present-day Southwest of Paraná, in addition to the municipal districts of Clevelândia and Palmas and the town of Mangueirinha (although they are located outside the present Southwest they were responsible for the genesis of this region). The colonization of the Southwest began from east to west, which in turn must be attributed to the generative logic of social-spatial formation, since it was from Palmas and Clevelândia that the settlement and construction of the necessary infrastructure occurred, responsible for the means of communication, through the roads and paths that made the connection, even if precarious, with the towns and villages of the south-east of Paraná state.

The first and main activities developed in the towns and villages of the Southwest were initially the extraction of Yerba-mate, soon followed by pig farming. Both the extraction activity of Yerba-mate, which was transported by mule trains, and the farming of pigs, which were carried "on foot" to the slaughterhouses, did not stimulate the implantation of a road infrastructure, which in turn diminished the intensification of the settlement in the region.

The next section gives continuity to the current section and, in turn, seeks to present the factors that contributed to the intensification of settlement, as well as discussing some of the particular characteristics of the origin of the urban nuclei of the two urban networks that were formed in the region.

\section{GENESIS OF THE CITIES OF THE URBAN NETWORKS OF FRANCISCO BELTRÃO AND PATO BRANCO}

The genesis of the urban nuclei of the Southwest of Paraná (Francisco Beltrão and Pato Branco Network) can be characterized, basically, by the collection and dispatch of agricultural products 
and the distribution of goods and services. In this way, the origin of the network of cities was related to the need for sale and purchase of products by the settlers. "[...] for a rural region every agglomeration is a center of consumption and allows it to leave the absolutely closed economy that prevents all progress" (DEFFONTAINES, 1945, page 308). To this genetic complexity of the urban network is added the role played by the Federal Government, which with the General Osório National Agricultural Colony (CANGO), brought the first urban traces to the formation of some cities of the region, especially Francisco Beltrão and Pato Branco. In addition, the presence of a sawmill contributed to the formation of a center with an industrial function.

The genesis of the urban centers in the Southwest of Paraná was derived from the distinct needs for the successful occupation of the region by producer and consumer colonizers and, according to Corrêa (1970b), this process can be synthesized in two ways.

In the first, the urban nuclei originated through a spontaneous occupation where the caboclo, "[...] owner of a 'grocery store [bodega]' and a 'holding', divided it into lots and sold them to the [...]" newly arrived settlers [...], and "merchants, tailors and blacksmiths, among others, giving rise to a settlement that would soon receive a chapel and other services. Subsequently the measurement and demarcation of the area of the future municipal seat took place" (CORREA, 1970b, p 127-128).

The second way that the origin and formation of the urban nuclei in the south-west of Paraná took place involves the official colonizing action (CORREA, 1970b).

The installation of a sawmill of a certain size was also a factor in the emergence of an urban nucleus. In a phase prior to colonization, a timber company installed a sawmill in the middle of the forest, after which an agglomerate of industrial functions emerged in the surrounding area, where some merchants settled to meet the needs of the workers. Soon, with the spontaneous penetration of colonizers of the areas belonging, or not, to the logging companies, this nucleus became the focal point for the settlers, gaining new functions related to the needs of the rural world [...] (CORREA, 1970b, p.129).

Therefore, once the settlers arrived, the areas previously divided up by the caboclos or by the colonizing companies and / or by CANGO, there was the immediate installation of the first industrial activity, the sawmills. According to Fresca (1990), in this respect, it is noteworthy that the installation of this activity also took place as the first industrial activity in the genesis of the cities of the west of São Paulo. The process occurred as follows:

$[\ldots]$ as the region was still covered by forest, deforestation was necessary to begin agricultural production. The sawmills were present in almost all the estates in order to transform the forest into raw material for construction. As a result of this, most of the buildings were made of wood (FRESCA, 1990, p.75).

Thus, the population displacement to the Southwest was fundamental and the industrialists, especially the loggers, also had a unique importance in the occupation, because along with the small farmers it was they who carried out the felling of the forests with their grandiose tree trunks. In this respect Voltolini (2000) tells us that:

The simultaneous or subsequent arrival of the loggers was received with joy by the farmer, in all the area with a dense coverage of the forest of Araucária. The owners of the sawmills, in turn, did not fail to express full satisfaction with the cordial deference [...] The settler, anxious to see his small farmland free for cultivation, even went so far as to pay for the felling of the pines that, even on the ground, were incommodious for years and years. Suddenly... a lottery! They took his timber away and even paid for it! [...] The logging companies in turn, began to acquire their industry's raw materials at derisory, highly rewarding prices that they set themselves and were accepted without reluctance by the 'happy' suppliers (Voltolini 2000: 74-75).

Therefore, the loggers who owned sawmills, were well received by the settlers and their economic activity was one of the focuses of the urban genesis in the region.

In the first phase of the formation of the urban nuclei, these made their ties with the agricultural areas of their hinterland. Thus, the city is the "gravitational focus of regional life" (BERNARDES, 
1964, p.3). The first links between the city and the rural area were between the small farmers who sold their produce and purchased consumer goods from small traders, also known in the region as those who owned a bodega (a small place trading in "dry and wet" goods). The development of urban centers, therefore, remained connected to the most distinctive needs of the colonial universe, "[...] but the differentiation between them proceeded according to the ease they had in becoming centers of larger and more populated areas $[\ldots]$ ". Among the centers that exercised spatial differentiation and stood out from the others are Pato Branco and Francisco Beltrão, "[...] whilst the other municipal seats remained active, either buying rural products or selling consumer goods, limited basically to the respective municipalities, that is, limited to the nearby rural areas... "(CORRÊA, 1970b, p.129).

Thus, Pato Branco and Francisco Beltrão, two centers that had important contributions from the state and federal public authorities (CANGO) and, it can be said, were the two centers chosen from their genesis to command the region and, in turn, their urban networks. It is worth mentioning that, in the initial phase of the formation of urban centers, Pato Branco had a level of centrality superior to Francisco Beltrão and, in this way, exerted regional dominance, linked to the distribution of goods and services. This position is noteworthy in view of the regional circulation that was maintained at least until the mid-1950s, as Pato Branco village benefited from being the end point of the highway from União da Vitória [this highway was the first highway in the region, which, in turn, was the gateway to regional colonization. It was expanded to Francisco Beltrão a few years later], acting vigorously in the commercialization of "pigs, hides and skins, already having about 1,000 inhabitants in 1940. Its store owners, caboclos, [...] carried out both transactions with the population of the region like the bodegueiros from the most remote areas, ensuring a regional function..." (CORREA, 1970a, pp. 95-96). Therefore, from the beginning, Pato Branco was a commercial trading post, the subsequent colonization by the "settlers" reinforced the regional function of Pato Branco.

Initially the birth of the urban centers took place on the eastern, central-southern and western peripheries of Southwest Paraná, the first five municipal seats and their territorial areas were created on December 14, 1952: Pato Branco, Francisco Beltrão, Capanema, Santo Antônio do Sudoeste and Barracão respectively, all dismembered from the municipal territory of Clevelândia (see figure 1).

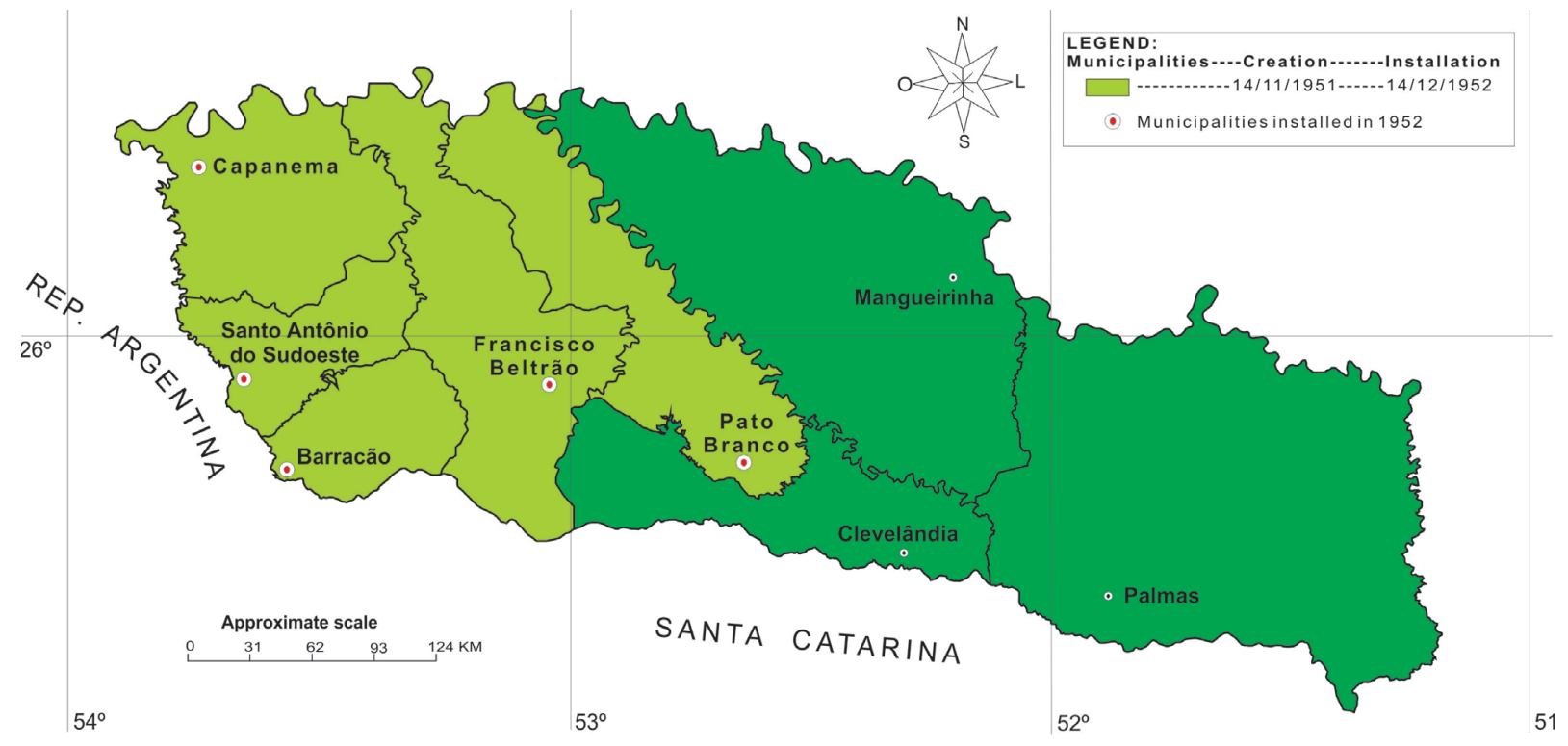

Figure 1 - Dismembering of the southwest region of Paraná in 1952

This was how the cities and the urban life of the Southwest of Parana emerged. The local cities that were being established began to play a fundamental role in the process of occupation of the territory. The presence of a city represented the possibility that the lands would be occupied quickly as a concrete fact. Each city served the basic needs of the urban and rural population in terms of goods and services (FRESCA, 1990). 
Therefore, the occupation carried out by the caboclos, prior to the arrival of the settlers, through the primitive agricultural system caused the devastation of some forest areas, an occupation that became the embryo of the genesis of many of the present cities, through their small towns. Among these first nuclei are the heirs of the herb period (the cycle of the Yerba-herb in Paraná) the settlement of Barracão, bordering Bernardo de Irigoyen / AG, Santo Antônio do Sudoeste, the border with San Antônio / AG and Pato Branco, which was known as Vila Nova in 1924, and functioned as an intermediary center in the transactions related to the Yerba-mate, carried out by the bodegueiros.

Therefore, the origin of the cities of Barracão, Santo Antônio do Sudoeste and Pato Branco, in the pre-colonial phase, was linked to the activity of the Yerba-mate. Pato Branco originated spontaneously and haphazardly and was extended thanks to the action of the government colonization body (Colony Bom Retiro), that installed the headquarters of a colonizing nucleus there and carried out the demarcation and division of lots.

From 1945, the population of the region expanded considerably with the advent of the migratory flow of colonists from Santa Catarina and Rio Grande do Sul. It is noteworthy that Pato Branco was the end point of the highway (with a bus line) coming from the areas of emigration, as well as the highway from União da Vitória. The buses to the settlement areas of the interior of the Southwest left from Pato Branco, especially for Vila Marrecas, now Francisco Beltrão.

In 1948, Pato Branco already exhibited differences that made it stand out from the other nuclei,

[...] there were retailers that distributed, among other things, sewing machines, safes, tires, radio sets, hardware, etc. It also had a coffee roaster, a saddlery, a mechanical workshop, an accounting office, a newly opened hospital equipped with an X-ray machine and one of its firms had a branch in Vila Marrecas, the current municipality of Francisco Beltrão (CORRÊA, 1970, page 132).

Pato Branco numbered 3,434 inhabitants in 1950 and so, as stated by the aforementioned author, it reinforced its level of centrality, acquiring new exclusive functions, such as: a junior high school, a radio station and bank branch.

Since 1950, Francisco Beltrão has gradually become an important collection center for rural production and a strong rival of Pato Branco in the distribution of consumer goods and services. In 1951, there were already "350 residential houses, a hospital, a church, a school, a pharmacy, 25 commercial houses, 2 mechanical workshops, 2 iron works, 5 wood shops, 2 mills, 2 tailors, 2 slaughterhouses, 3 hotels and 1 soda factory" (MARTINS, 1986, p.33).

It is important to point out that in Francisco Beltrão, in addition to the forces promoted by CANGO (Federal authority) that gave the first incentives for industrialization in the region, through them "the first saddlery, carpentry, pottery and mechanical workshop [...]" emerged (LAZIER, 1997, pp. 40-1). The influence of industry also played a major role in the development, especially of the urban area, and one of the examples cited is the Camilotti Camidoor industry, which settled in 1954 and today has its industrial plant in the same location, which in turn, corresponds to the city center (the heart of the city) and is a nuisance to the neighboring residents. In conversations, in the industry and with the local authorities, it was verified that there is still not a concrete plan for the municipality or intentions on the part of the company to reallocate the industrial plant.

[...] the expressive rural density, resulting from the occupation of small polyculture landowners, makes the regional cities highly important in the relational life created by trade and services. It is through them that the transactions related to the collection and dispatch of agricultural products and the consumption of industrialized products and services are carried out. [...] regional cities are geared much more towards trade and the provision of services, being at the same time centers for the collection and dispatch of agricultural products and the distribution of goods and services. It is mainly through these types of relationship that the Southwest participates in a broader spatial set that has its main focus in Curitiba, Rio de Janeiro and São Paulo (CORRÊA, 1970b, p.11). 
Such relationships linked to tertiary activities provide the formation of an urban network in the Southwest, reflecting the density of the rural population and also the diversity of their relationships.

Next came the founding of two more municipal seats in the Southwest, Chopinzinho and Coronel Vivida, that were dismembered from Mangueirinha and created on December 14, 1955 (see figure 2). The genesis of the two municipalities was linked to the action of an official colonization organ that carried out the demarcation and the subdivision, Chopinzinho had an unusual beginning as the headquarters of the Military Colony of Chopim, established in 1882, which slowly structured the basis for forming an urban nucleus.

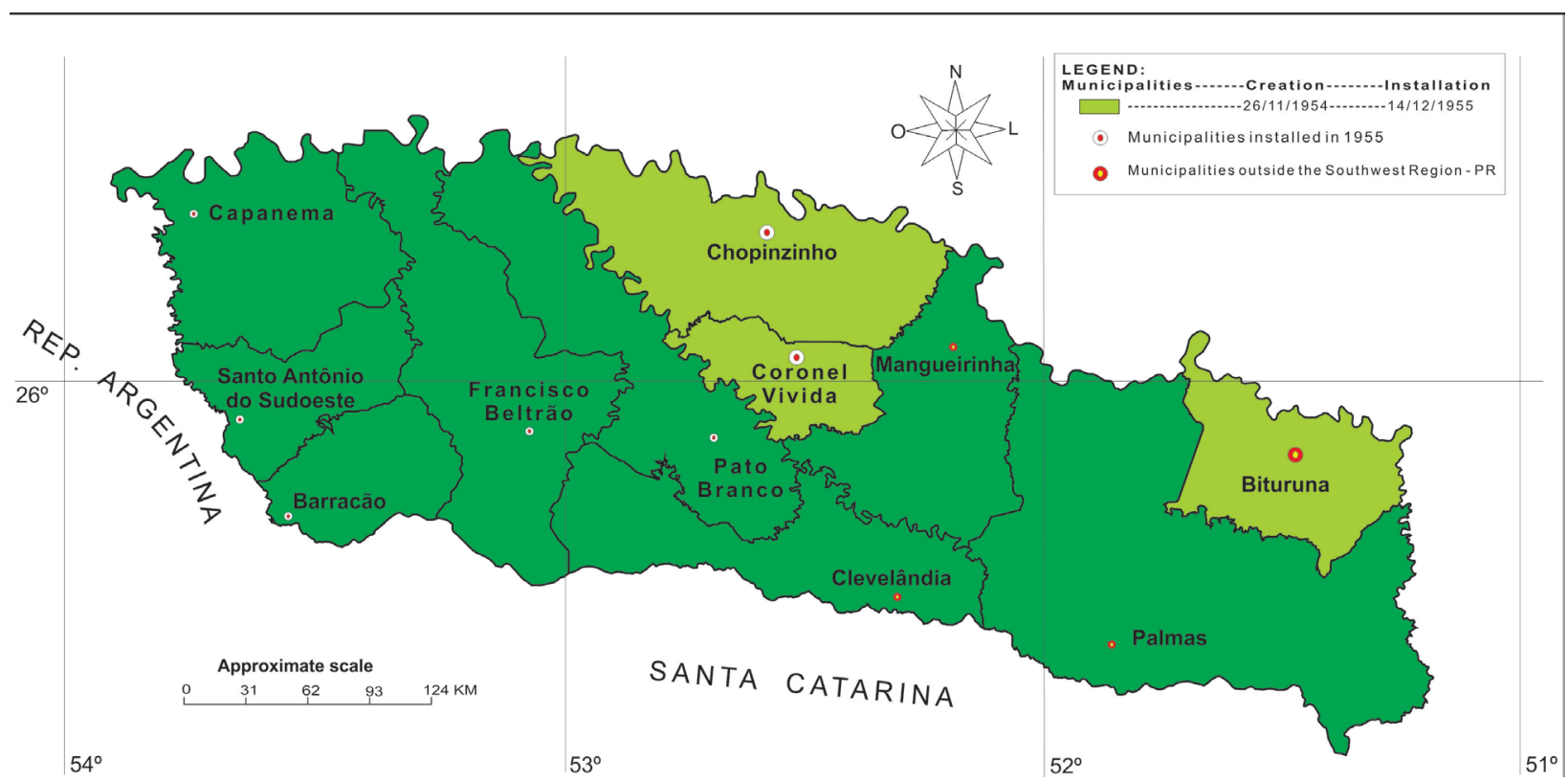

Figure 2 - Dismembering of the southwest region of Paraná in 1955

In 1961, eight more municipal seats were created, as shown in figure 3. São João was dismembered from Chopinzinho; Mariópolis, Vitorino and Renaissance were dismembered from Clevelândia; Dois Vizinhos was dismembered from Pato Branco; Marmeleiro was dismembered from Francisco Beltrão, Ampere was dismembered from Capanema and Santo Antônio do Sudoeste; and lastly, Pérola do Oeste was dismembered from Capanema.

The cities of Dois Vizinhos, Ampére, Pérola do Oeste, Vitorino, Renascença, Marmeleiro and São João originated focused on urban life as a bodega. The processes constituting these urban nuclei took place essentially in the same way in Dois Vizinhos, where there were two bodegas around $1948 / 1949 / 1950$ that were the first centers of urban life, they exchanged consumer goods from the Portuguese-Brazilian population, mainly skins and hides. "[...] Around 1953, with the growing penetration of settlers in the vicinity, the European-born bodegueiro divided up his 'holding' and built a chapel; soon other merchants and the first services to meet the needs of more and more settlers emerged [...]" (CORRÊA, 1970b, p. 128). 


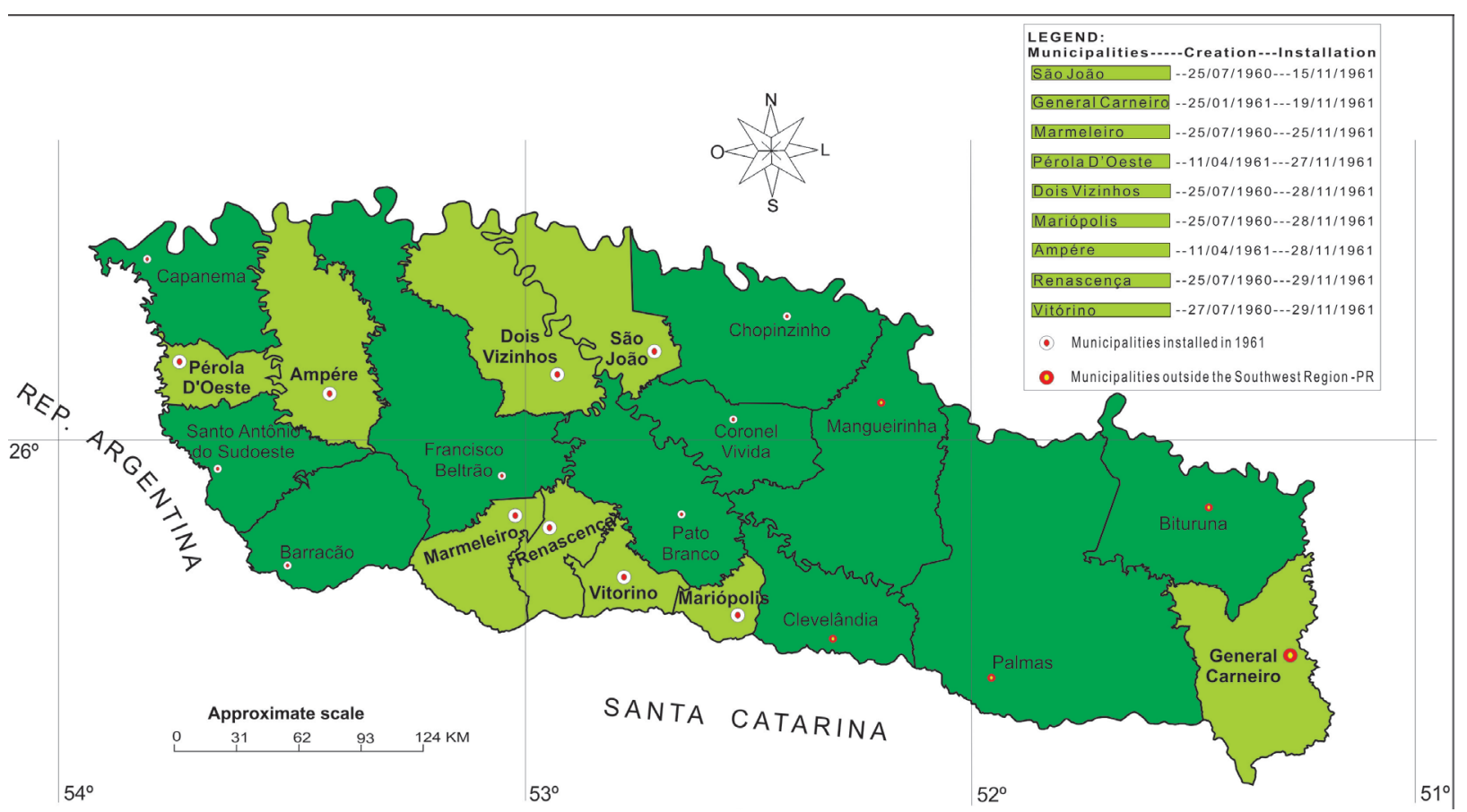

Figure 3 - Dismembering of the southwest region of Paraná in 1961

The urban nucleus of Mariópolis originated from the action of the colonizing companies "Apucarana" and "Commercial". It is noteworthy that the origin of the municipality of Mariópolis was linked to the São Francisco Sales Farm, which from the 1930s onwards received the first settlers to develop colonization, but it was only at the end of the 1940s that the Clevelândia Industrial e Territorial Ltda. (CITLA) acquired part of the area (land in litigation) and through the colonizing agents began the sale of the colonies (each with 10 alqueires). In 1949, CITLA built the first sawmill that contributed to the felling of the pine trees and the construction of dwellings. During the 1950s the sawmills multiplied, in addition to the intensification of settlement.

The next four urban centers established date from 1963, São Jorge do Oeste that was dismembered from São João; Verê was dismembered from Dois Vizinhos; Realeza was dismembered from Ampére and Planalto that was dismembered from Capanema.

The origins of the cities of Planalto and São Jorge do Oeste were linked to the action of the "Apucarana" and "Comercial" colonizing companies.

Verê's genesis began in the 1920s, with the penetration of the Portuguese-Brazilian population and from the 1950s onward, the first focuses of urban life were structured by newly arrived settlers who set up small businesses to cater to the established population and the new arrivals. In addition, the first settlers were responsible for acquiring land from the caboclos and dividing it up.

Realeza began with the creation of a sawmill, in a phase that preceded colonization, as Corrêa mentions (1970b, 129) "[it] arose as a result of the installation, around 1960, of a sawmill belonging to CAZACA Industries Ltda., which divided up the lands around the industrial establishment. The occupation of the present municipality occurred after the urban nucleus was established [...]". In this way, the industry served as the first focus of urban life, since the families of the workers arrived and built their homes with pinewood that was abundant at the time and that the sawmill itself supplied and deducted from their wages. These families settled near the sawmill, forming a village (urban focus) and it was from these families that the first small businesses originated to serve the local consumer market that was gradually formed, made up of workers and settlers.

In 1964, five more municipal seats were established, as shown in figure 4: Santa Izabel do Oeste that was dismembered from Ampére; Salto do Lontra and Enéas Marques that were dismembered 
from Francisco Beltrão; Itapejara do Oeste that was dismembered from Pato Branco and Francisco Beltrão, and finally Salgado Filho that was dismembered from Barracão.

The genesis of Santa Izabel do Oeste was linked to a sawmill (industrial function).

The urban nuclei of Enéas Marques, Itapejara do Oeste, Salto do Lontra and Salgado Filho originated in a similar fashion to the center of Dois Vizinhos. That is to say, they were nuclei originating from the action of a caboclo / settler who, normally possessing an area, divided it and sold several parts to the new arrivals. In addition, they also had small businesses serving the population and collecting and shipping products from the rural area.

In the 1960s, most of the Southwest's population resided in the countryside. In order to have an idea of the intensity of this reality, it is sufficient to verify the data of the Demographic Census (IBGE, 1960), which informs that the total population of the Southwest consisted of 225,347 inhabitants and the degree of urbanization was approximately $12 \% ; 88 \%$ were rural dwellers. These data reinforce that the extraction of the Yerva-mate and pig breeding, the basic economic activities prior to the timber cycle in the Southwest, contributed little to the occupation process. It was during the timber cycle, responsible for the clearing the forest, that space was opened up for rural production; the intensification of the occupation of the Southwest was achieved by small commercial producers.

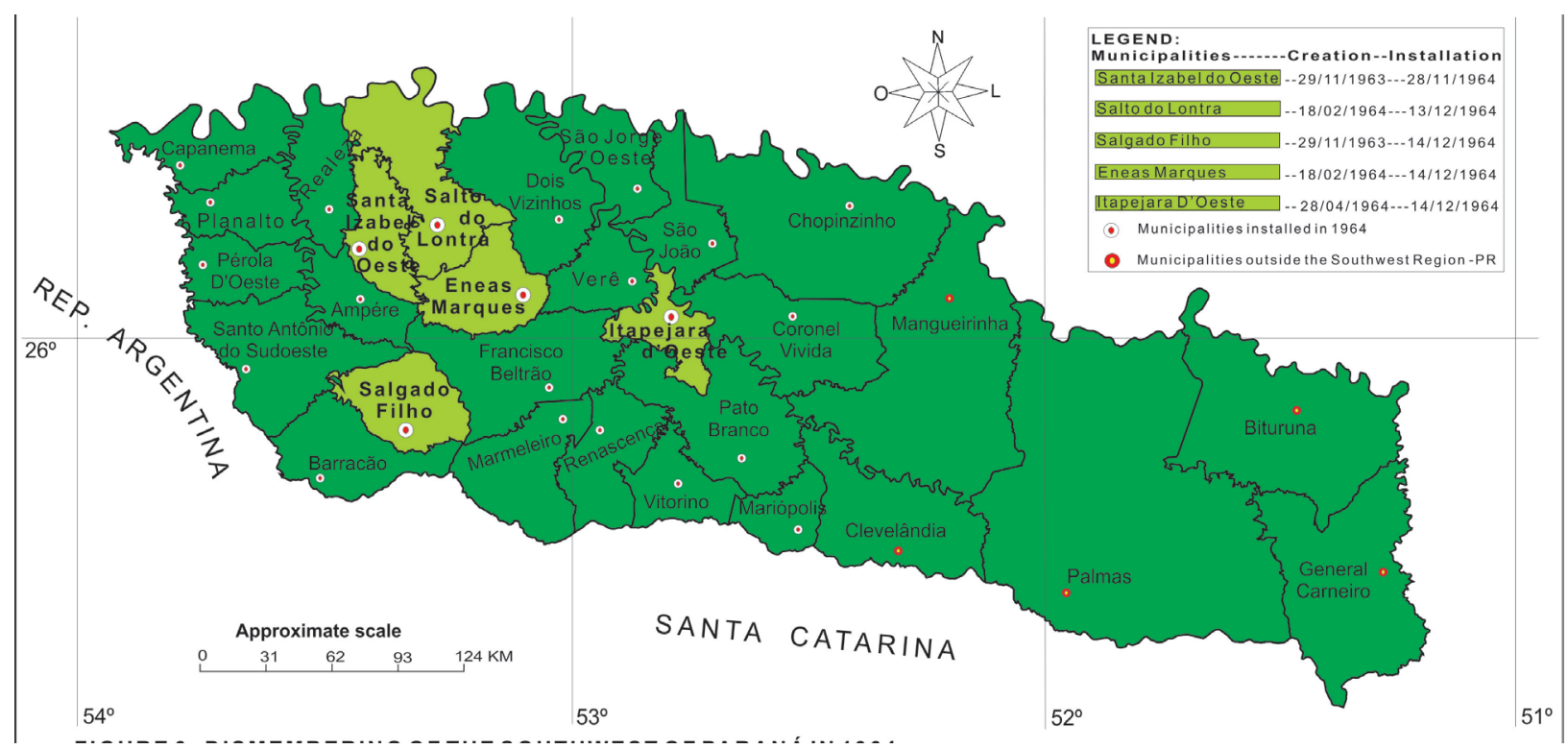

Figure 4 - Dismembering of the southwest region of Paraná in 1964

Thus, during the 1950s and 1960s, the Southwest of Paraná saw the emergence of the first urban centers and their intensification, as twenty-four municipal headquarters were founded. Oliveira (2001) reinforces the analysis, for him " [...] in the Southwest, wood and livestock were the most dynamic activities, generating a tendency for the proliferation of urban nuclei capable of supporting activities in those branches of the economy" (OLIVEIRA, 2001, p.35).

In 1960, all the municipalities of the Southwest had rural populations superior to the urban ones. The rural population of the municipality of Pato Branco was formed by 41,248 inhabitants and by an urban population of 10,333 inhabitants. Its degree of urbanization was $20 \%$ (IBGE, 1960). Noting that, in this period, Pato Branco was the main regional urban nucleus.

In this decade, Francisco Beltrão disputed the position of the main urban center in the Southwest, with a rural population of 50,507 inhabitants and an urban population of 4,989 inhabitants; its degree of urbanization was only $9 \%$ (IBGE, 1960).

From the data presented, we can consider that Pato Branco, in addition to exerting a prominent centrality through the specialization of its services, had the highest degree of urbanization in the region. Thus, the "hegemony" of Pato Branco was clear, both in terms of population dynamics and urban dynamics. It is worth mentioning that the Southwest only had 12\% of urban inhabitants, Paraná 
reached $31 \%$ and Brazil $45 \%$. That is, the region and all the individual centers were far below the state and national rate of urbanization, due to it being a region of late and / or recent colonization.

From the 1950s, the function of the "boca de sertão " (to use the terminology coined by Pierre Monbeig) was transferred to Francisco Beltrão which, during the aforementioned decade became an important center for collecting rural production and distributing goods and services, thus becoming Pato Branco's rival. However, according to Corrêa (1970b), Pato Branco's entrepreneurs, made up principally of merchants linked to the colonist trade purchasing and selling products, perceived that Francisco Beltrão threatened Pato Branco's hegemony and, with a view to resuming the process of regional "supremacy", the businessmen took the path of specializing their activities. In order to do so, "[...] with the existence of a market in expansion, both quantitatively and qualitatively, thanks to the improvement of the colonists' standard of living ... and the expansion of settlement ...". An illustrative example refers to the case, "[...] of the company O. N. Amadori \& Cia Ltda, whose origin dates back to the late 1940s as a colonist trade firm; in 1957, it became a Ford dealer [...] “ (CORRÊA, 1970b, p. 131).

Also, some distributors sought to specialize through their contacts with companies from outside, which was partially guaranteed by the expansion of the market. The example to be highlighted here refers to "[...] the DIVECAR firm, whose origins go back to 1947, when a mechanic shop and auto parts trade was founded: in 1959, it became a Chevrolet dealership". As early as 1968, the Ford and Chevrolet dealerships were "[...] unique functional attributes of Pato Branco [...]". It is therefore the main center of the Southwest, highlighting the fact that, in this urban center, new firms for the distribution of goods and services (dental material, in 1960, eye, ears, nose and throat doctors in 1963, and regional administrative bodies from 1962 to 1967). As a result of successive specialization, it became possible to "[...] disconnect the Southwest of Paraná from the orbit of influence of União da Vitória-Porto União, placing it under the direct influence of the regional metropolis, Curitiba" (CORRÊA, 1970b, P.131-133).

This hierarchical position achieved by Pato Branco is attributed to its merchants' ability to take advantage of the situation they had in the near past, when they saw that transformations in the social-spatial relationships in the Southwest were underway and, aiming to obtain greater profitability, they sought to guarantee the exclusive offer of products for the region and / or the opening of branches of their companies in Francisco Beltrão and other centers in the Southwest. This made it possible for Pato Branco to continue as the main centrality of the Southwest.

The 1970s were marked by a greater demographic dynamic in the Southwest, where the process of rural exodus became noteworthy. The urban network in this period was formed by a greater number of urban centers, which in turn, increased its degree of complexity, mainly due to the growing demand for goods and services, generated by the increase in population. However, as until the 1970s the economy of the Southwest had a weak dynamism, Corrêa (1970b) understands that the cities of the region were a network of the standard Christallerian type, since the southwestern production was based on the primary sector. Few cities concentrated the dispatch / distribution business, as well as banking, education, health services, etc. Thus, relations in the network outbalanced the tertiary interactions, reducing the flows of the regional productive sector to the national / global economy.

In fact, the dynamic of the productive sector was reduced until the 1970s, according to data from the IBGE Industrial Census, which showed that regional industrialization was composed mainly of the timber sector. This sector was responsible for generating approximately $73 \%$ of the jobs in industry and $70 \%$ of the value of the production.

According to the Demographic Census of 1970, the Southwest of Paraná, totaled 434,324 inhabitants (IBGE, 1970). As a result, the degree of urbanization in the region increased to around $17 \%$. However, the degree of rural inhabitants still prevailed, at $83 \%$.

At this juncture, Pato Branco, with 15,420 urban dwellers, continued to have the largest number of urban inhabitants of the Southwest, and its rural population numbered 17,984 people. 
Its degree of urbanization was $45 \%$ and showed a trend to surpass the rural population during the 1970s (IBGE, 1970).

During this period, Francisco Beltrão had 13,413 urban dwellers and 23,394 rural dwellers and its degree of urbanization reached $36 \%$ (IBGE, 1970).

With regard to the structured urban network in the first study on the Regions of Influence of Cities (REGIC), which was called the Division of Brazil in Urban Functional Regions, edited by IBGE in 1972, the urban center of Pato Branco had a level of centrality superior to the center of Francisco Beltrão.

Pato Branco's network had twenty-three urban centers, remembering that this included Francisco Beltrão and the centers of its network. This network had 80,157 urban inhabitants, which represented $17.96 \%$ of urbanization. The network of Francisco Beltrão had 16 centers and 51,866 urban inhabitants, who made up $16.05 \%$ of urbanization. Therefore, Pato Branco's network had a certain advantage in demographic terms and in its dynamic of interactions.

At the end of the 1970s and during the 1980s, there were transformations in Francisco Beltrão's urban network, when companies in the commerce and services sector were established, as well as industrial plants (in this sector SADIA, currently BRF stands out).

According to data from the Demographic Census of 1980, the Southwest of Paraná had 527,645 inhabitants (IBGE, 1980). Nevertheless, its rural population was larger than the urban one. The census registered 356,822 rural inhabitants and 170,823 urban ones. The degree of regional urbanization reached $32.37 \%$ (while Paraná totaled 58.93\%).

In 1980, the degree of urbanization in Pato Branco reached 68.84\%, with 32,255 urban dwellers compared wth 14,598 rural ones (IBGE, 1980). Francisco Beltrão also reached an urban population superior to its rural one, totaling 28,988 urban inhabitants, compared with 20,625 in the rural areas; a degree of urbanization of $58.43 \%$. Only these two centers in the region managed to surpass a $50 \%$ rate of urbanization; seven centers reached indexes between 30 and $49 \%$ and the remaining 15 municipalities were below $30 \%$ of urban dwellers (IBGE, 1980).

The most sensitive changes in the region occurred in the dynamics of agriculture and industry, as in the 1970s the modernization of agriculture or the insertion of capitalism into agriculture, reached the Southwest, which underwent transformations already taking place in other regions of the country and Paraná. Crocetti (2012) verified that from the "[...] 1970s, the region also started to produce for the foreign market, with the growth of the soybean crop. Based on the regional production of grains, pig and poultry farming has also been established, and milk production is currently expanding and modernizing" (CROCETTI, 2012, p.120).

In the 1970s there were 667 manufacturing units in the Southwest, which increased to 830 in 1980.

In relation to the tertiary sector, in the cities with the highest hierarchical level in the region, Pato Branco and Francisco Beltrão, with the increase of the population and the expansion of the local consumer market, the bodegas gradually gave way to modern auto-service facilities.

In the REGIC, edited by IBGE in 1987, Pato Branco was denominated the Regional Capital at the level of centrality, continuing to have a level of centrality superior to Francisco Beltrão, which at the time was denominated as a Sub-Regional Center. The latter polarized 17 cities into its network, nevertheless, it continued being polarized by Pato Branco, that is, in addition to polarizing 19 cities, Pato Branco also included the centers of Francisco Beltrão's network. It is noteworthy that Pato Branco continued to belong to the urban network of Curitiba.

The Pato Branco network stood out, with an urbanization of $53.86 \%$, higher than the urban statistics of the Southwest that were only $32.37 \%$, but inferior to the $58.93 \%$ urbanization rate of Paraná.

The network of Francisco Beltrão included 13 urban centers and had 30\% of urban inhabitants, an index below the region, the State and the network of Pato Branco itself. 
However, Francisco Beltrão's network stood out regarding the number of urban inhabitants, who numbered 94,322 people, which in turn represented almost 2.5 times the number of inhabitants of the cities of the Pato Branco network.

In 1983, Nova Prata do Iguaçu was founded (dismembered from Salto do Lontra) and Pranchita (dismembered from Santo Antônio do Sudoeste). The last municipal seat installed in the Southwest in the 1980s was Sulina, dismembered from Chopinzinho in 1989.

The Demographic Census of 1991 shows that the urbanization process of the Southwest of Paraná continued to grow every decade. This publication presented a total of 523,958 inhabitants in the Southwest, of whom 277,238 were rural dwellers and 246,720 lived in urban areas. Therefore, the degree of urbanization in the Southwest reached the mark of $47 \%$, and only four municipalities had urbanization rates above 50\% (IBGE, 1991).

In 1991, the municipality of Pato Branco had a rural population of 12,269 inhabitants and an urban population of 43,406. Its degree of urbanization reached 77\%. Francisco Beltrão had 45,622 urban inhabitants and a rural population of 15,650. Consequently, its degree of urbanization rose to $74 \%$. Urban growth that, in a way, already presented a reasonable consumer market for industrial goods.

Another center that stands out regarding its urban population is Dois Vizinhos, since it reached 43,406 urban inhabitants, compared with 18,065 rural inhabitants. Data that provided a degree of urbanization of $55 \%$. Among others, this fact has gained relevance as a result of the installation of the Frigorífico da Sadia S / A, which, in turn, generated the first impulses of demographic and business attraction to the city, thus expanding its urban dynamics (IBGE, 1991).

In 1993, seven more municipalities were established in the Southwest (Figure 5), namely: Bom Sucesso do Sul (dismembered from Pato Branco); Saudade do Iguaçu (dismembered from Chopinzinho); Boa Esperança do Iguaçu and Cruzeiro do Iguaçu (dismembered from Dois Vizinhos); Flor da Serra do Sul (dismembered from the municipalities of Barracão and Marmeleiro); Pinhal de São Bento (dismembered from Santo Antônio do Sudoeste) and Nova Esperança do Sudoeste (dismembered from Enéas Marques). It should be noted that the last five are part of the current Francisco Beltrão network (REGIC, 2008).

The last three municipal seats created in the Southwest of Paraná to date were: Bela Vista da Caroba (dismembered from Pérola do Oeste); Bom Jesus do Sul (dismembered from Barracão) and Manfrinópolis (dismembered from Salgado Filho), also highlighting that the municipality of Coronel Domingos Soares in the region of Campos de Palmas was also founded in 1997. Therefore, since 1997, the current municipal configuration of the Southwest of Paraná was formed, noting that for this, we need to exclude the municipalities located in the Campos de Palmas, that is, the municipalities that are outside the Southwest mesoregion, even if these were part of the genesis of the Southwest, they are part of another social-spatial formation, as well as another mesoregion (IBGE, 1990).

In the year 2000, the total population of the Southwest decreased to 472,626 inhabitants, compared to the 523,958 inhabitants registered in 1991. Its rural population also declined significantly, from 277,238 inhabitants in 1991, to 186,192 inhabitants in 2000. However, the urban population continued to grow from 246,720 in 1991 to 286,434 inhabitants in 2000 . These data provided a degree of urbanization of $61 \%$ (IBGE, 2000).

Among the 37 urban centers in the Southwest, 18 had an urbanization rate of over $50 \%$, and the remaining 19 centers did not reach the rate of $50 \%$. 


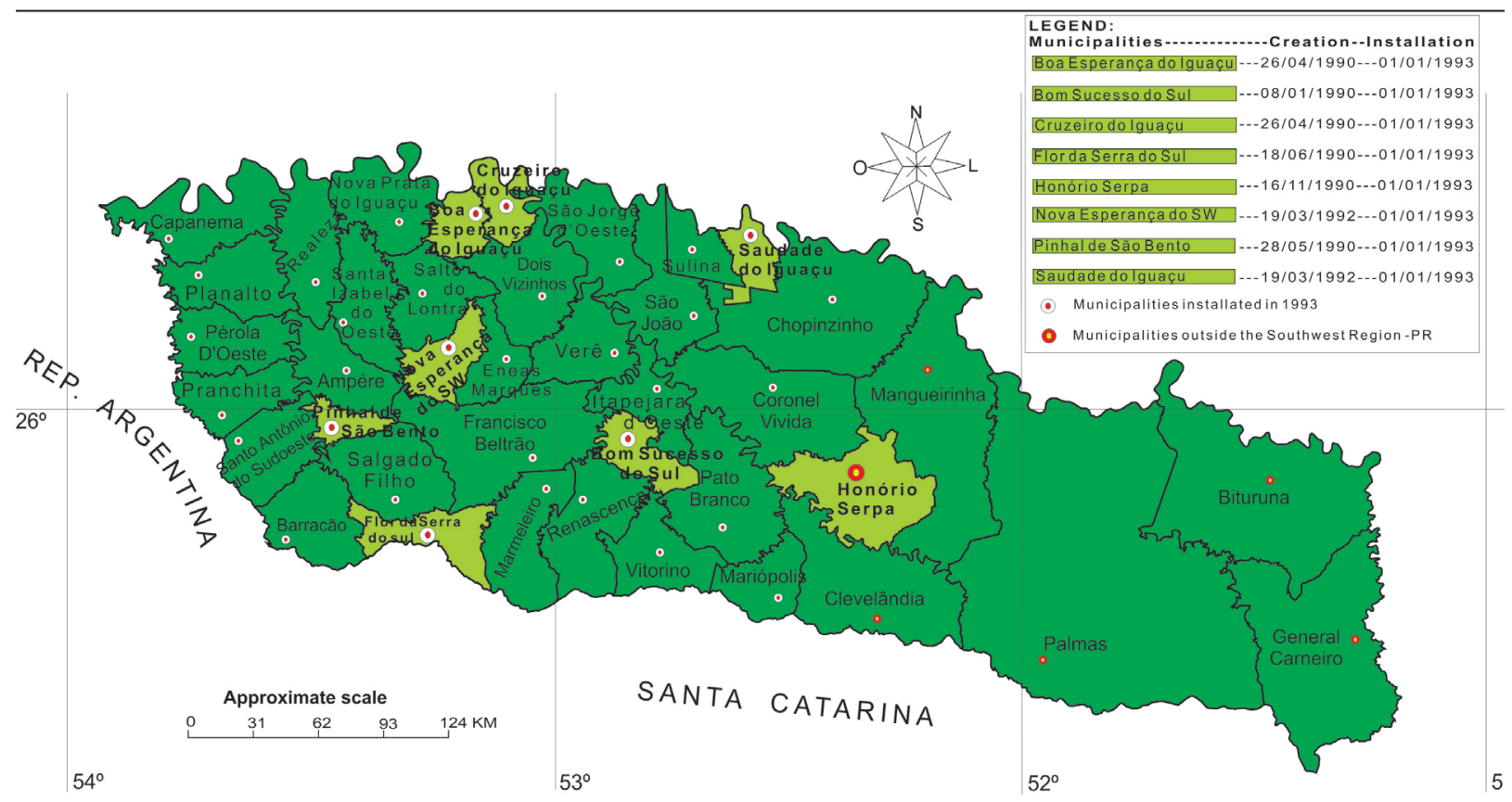

Figure 5 - Dismembering of the southwest region of Paraná in 1993

In this urban context, the city with the highest degree of urbanization remained Pato Branco, which reached $91 \%$ in the year 2000. To this end, its urban population in the same year was 56,805 inhabitants and its rural inhabitants totaled 5,429. Francisco Beltrão surpassed all the municipalities, in relation to total population. With its 67,132 inhabitants, it was the most populous municipality in the Southwest of Paraná. However, its urban population was still smaller than that of Pato Branco, totaling 54,831 inhabitants in 2000, what made it the most populous municipality was its rural population of 12,301 inhabitants, more than twice the rural inhabitants of Pato Branco. Therefore, its urbanization only totaled $81 \%$ (IBGE, 2000).

In the REGIC carried out in 1993, but only published by the IBGE in the year 2000, the urban network structured by the center of Francisco Beltrão was no longer polarized by Pato Branco and became polarized by the capital of the State of Paraná, Curitiba, which also polarized Pato Branco. In this REGIC (2000b), Francisco Beltrão polarized 27 urban centers in its network and Pato Branco polarized 24 centers. These two centers had a strong to medium level of centrality.

Pato Branco reached $91 \%$ urbanization, a very expressive rate that makes this center play an urban dynamic in relation to its commercial and services activities of great value for its area of influence. Even if this urban network is not the central focus in this study, we can say that the centrality of Pato Branco, even losing reasonable strength, according to the REGIC of 2000 (an example is that it was only in this research that the IBGE points out that Pato Branco stops polarizing Francisco Beltrão), continued to be the most dynamic in the 1990s, above all, in relation to urban activities, since it exerted the function of university, medical-hospital, and commercial pole of more sophisticated products, etc.

In 2000, Pato Branco, started to stand out as a regional technological center, through incubators of technology-based companies, initially mostly resulting out of research by UTFPR academics - Pato Branco Campus, who were based at the Center for Industrial Technology of the Southwest (CETIS), an industrial condominium organized in 1998 by COPEL, the Central Laboratory for Research and Development (LACTEC), Pato Branco City Hall and the Federal Government, with support from the current CEFET UTFPR.

According to the REGIC of 2000, after the center of Francisco Beltrão, the centrality of Dois Vizinhos (polarized by Francisco Beltrão) was the most dynamic, since according to the Census (IBGE, 2000), it totaled an urban population of 22,382 inhabitants and a rural population of 9,604 residents, reaching an urbanization rate of $69 \%$. 
From the 1990s, it is evident that industry and agroindustry began to dominate the network, a domination that began in the 1980s, but that after the first two quarters of the 1990s increased their share of total establishments and jobs. The tertiary sector began to expand in the 1990s, but already in the 1970s there were car dealerships in the region, many of them were brought by the owners in Pato Branco who did not want to lose the consumer market of Francisco Beltrão. In 1972 the Meimberg Group set up in Dois Vizinhos with the acquisition of Divel, a Volkswagen dealership, a group that currently owns most of the car dealerships present in the network centers.

From the concessionaires came the fuel stations, first those of the Petrobras brand (BR) and as the number of vehicles increased, the gas stations increased, which together with the concessionaires expanded the interactions in the network. Interestingly, since that time (1970s and 1980s) automobiles came directly from the assembly plants to Francisco Beltrão and / or to the headquarters city of the concessionaire that had made the sale. Therefore, they did not need to go through centers with a higher hierarchy in the Brazilian urban network, before arriving, for example, in Dois Vizinhos. Thus, for this sector, part of Christaller's (1966) propositions do not apply, but in relation to the dynamics of the network as a whole, these propositions present some degree of validation, since in centers of higher hierarchy there were (and there still are), some wholesale companies responsible for products that are purchased from businesses located in centers of a higher hierarchical level and resold to centers lower down in the hierarchy; the inverse is also true.

According to REGIC published in 2008, the urban network of Francisco Beltrão is formed by the city of Francisco Beltrão plus 24 centers and is polarized by Cascavel (figure 6). Francisco Beltrão and Dois Vizinhos have the highest percentage of urban population, $85.43 \%$ and $77.67 \%$, respectively (IBGE, 2010), as well as being the two largest centers of the network, with the highest hierarchical levels (Francisco Beltrão, "Sub-regional Center A" and "Dois Vizinhos, "Center of Zone A"); they also have the largest number of industrial, commercial and service activities.

Based on REGIC (IBGE, 2008), the Pato Branco network is formed by the city of Pato Branco plus 13 centers and is polarized by Curitiba. Pato Branco has the same hierarchical level as Francisco Beltrão, that is, "Sub-regional Center A".

Francisco Beltrão's network developed a reduced urbanization, since its level was only $16 \%$ in 1970 , evolving to $67.42 \%$ in 2010 . The rate of urbanization was below the national rate $(84.4 \%)$, lower than the State $(85 \%)$, lower than that of Southwest of Paraná $(70.23 \%)$ and below the rate of the Pato Branco network (76.78\%). This fact corroborates that the network has a low rate of urbanization, that is, of the network's 25 centers, nine have a larger percentage of rural population and six have a rural population in the $40 \%$ range (IBGE, 2010).

Another important item to highlight is the current road network in the Southwest of Paraná, because highways are the means by which the population and production are transported and the better these infrastructures are, the more benefits they will bring to urban and regional development. 


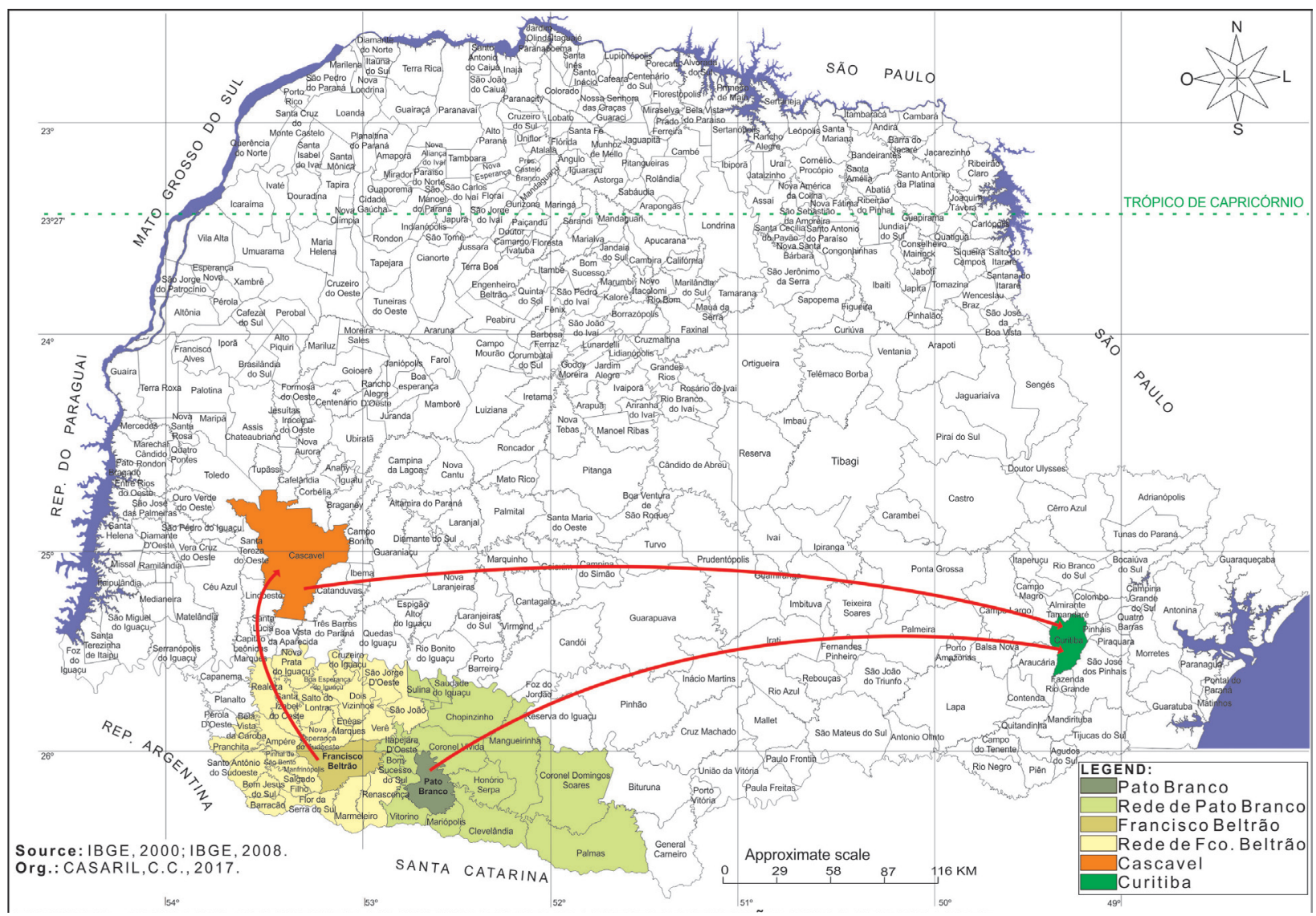

Figure 6 - Centers of the urban network of Francisco Beltrão and Pato Branco

We can consider most of the centers of the network of Francisco Beltrão and Pato Branco as local cities, those that are at the confluence of the rural with the urban (CORRÊA, 2011); it is an arduous task to differentiate them. Nevertheless, we can say that the two main centers of their respective networks, Francisco Beltrão and Pato Branco are small cities that are on a higher level due to their dynamics. They can even be considered as being on the threshold between the small city and the medium-size city, but above all, these are regional cities, since they have the capacity to organize and direct regional life. On the other hand, because they have a population dynamic and expanding urban activities, the cities of Realeza, Santo Antônio do Sudoeste, Ampére and São João can also be considered small cities (however, at a lower level than the main centralities of the network), especially the three last centers, which have considerable industrial dynamics; it is through these productions that they are inserted in the network.

\section{FINAL CONSIDERATIONS}

In the course of this work, the social-spatial formation Southwest of Paraná was verified, as well as the formation of the urban network of Francisco Beltrão and Pato Branco and the genesis of their respective cities.

The social-spatial formation of the centers of the network (and of the south-west of Paraná) based on the small commercial production was extremely important for the occupation process and gave rise to the genesis of the cities and the process of industrialization, linked to a small business (the bodegas) and local crafts (producers of household utensils and tools), as well as the sawmills that came later and helped to clear the area, freeing it up for production. Thus, many artisanal activities were carried out in rural establishments and until the mid-1970-1980s, they had not yet completed their disintegration of the countryside, to become industrial activities (division of labor), an explanation given by Rangel (1990). 
The first foci of urban life in the south-west of Paraná appeared alongside the regionally known bodegas (dry and wet trades). This is where the colonists (small landowners) and the bodegeiros met, carrying out transactions with the population of the whole region and with the bodegeiros from the more remote areas, assuring a regional function. Therefore, the development of the urban centers remained connected to the most distinct needs of the colonial universe.

The local cities that were being established began to play a fundamental role in the process of occupation of the territory. The presence of a city represented the possibility that the lands would be occupied quickly as a concrete fact. Each city served the basic needs of the urban and rural population in terms of goods and services (FRESCA, 1990).

The urbanization process of Southwest of Paraná occurred in a gradual but slow process. Currently, the regional urbanization rate has reached approximately $70 \%$, that is, when compared with other regions, or even with Paraná and Brazil, it is verified that the rate of urbanization in the region is slightly reduced. The fact that helps understand this issue is that the region consists of small and medium family farms, which allows us to understand why more than $50 \%$ of the municipalities have an urbanization index of up to $60 \%$, most of which have a rural population rate above the urban.

Thus, most of the urban centers are at the confluence of the rural and urban, which represents a central aspect in relation to the urban network, since the population of these localities needs to travel to Francisco Beltrão or Pato Branco (which are regional cities) to obtain medical and hospital services, secondary and higher education, in addition to seeking more options of commerce and services.

Therefore, we have used the tool of social-spatial formation, which joins the perspective of historical geography, since it seeks to analyze the historical process, seeking to unveil the pillars of spatial organization / transformation that stem from the unity of continuity and discontinuity. Thus, historical geography is fundamentally a geographical study of the past, essentially it is a geographical study, not a historical one.

\section{ACKNOWLEDGMENTS}

To the Coordination of Higher Education Personnel (Capes) for the scholarship received through the National Postdoctoral Program (PNPD / Capes).

\section{BIBLIOGRAPHICAL REFERENCE}

BERNARDES, L. M. C. O Rio de Janeiro e sua Região. Rio de Janeiro: IBGE/CNG, 1964.

BERNARDES, N. Expansão do povoamento no Estado do Paraná. Revista Brasileira de Geografia, 1952. BESSA, K. A dinâmica da rede urbana no Triângulo Mineiro. Uberlândia: [s.n.], 2007. 348p.

BRAUDEL, F. As Cidades. In: BRAUDEL, Fernand. Civilização Material, Economia e Capitalismo, Séculos XV, XVIII. Vol. 1. São Paulo: Martins Fontes, 2005. p. 439-465.

CARNEIRO, P. A. S. Questões teóricas e metodológicas da Geografia Histórica. ANAIS... IX ENANPEGE. p. 1-8, 2011.

CHOLLEY, A. Observações sobre alguns pontos de vista geográficos (part. 1). Boletim Geográfico. Rio de Janeiro: IBGE, n.179, p. 139-145. 1964. Disponível em <http://biblioteca.ibge.gov.br>. Acesso em 05/08/2008.

CHOLLEY, A. Observações sobre alguns pontos de vista geográficos (part. 2). Boletim Geográfico. Rio de Janeiro: IBGE, n.180, p. 267-276. 1964. Disponível em <http://biblioteca.ibge.gov.br>. Acesso em 05/08/2008. CHRISTALLER, W. Central Places in Southern Germany. Prentice-Hall, Inc. Englewood Cliffs, 1966. CORREAA, R. L. Os estudos de redes urbanas no Brasil. Revista Brasileira de Geografia, Rio de Janeiro, v. 29, n. 4, p. 93-116, out./dez. 1967. Disponível em <http://biblioteca.ibge.gov.br>. Acesso em 07/06/2007. 
CORRÊA, R. L. O sudoeste paranaense antes da colonização. RBG, v.32, n.1, p. 87-98, jan./mar. 1970a. Disponível em $<$ http://biblioteca.ibge.gov.br>. Acesso em 07/06/2007.

CORRÊA, R. L. Cidade e Região no Sudoeste Paranaense. RBG. v.32, n. 2, p. 3-155. 1970b. Disponível em $<$ http://biblioteca.ibge.gov.br $>$. Acesso em 07/06/2007.

CORRÊA, R. L. A rede de localidades centrais nos países subdesenvolvidos. Revista Brasileira de Geografia, Rio de Janeiro, v. 50, n. 1, p. 61-83, jan./mar. 1988. Disponível em <http://biblioteca.ibge.gov.br>. Acesso em 08/06/2007.

CORRÊA, R. L. A rede urbana. São Paulo: Ática, 1989. 96p.

CORRÊA, R. L. Interações Espaciais. In: CASTRO, Iná E. de; GOMES, Paulo Cesar da C.; CORRÊA, Roberto L. (Org.). Explorações geográficas. RJ: Bertrand Brasil, 1997. p. 279-318.

CORRÊA, R. L. Estudos sobre a rede urbana. Rio de Janeiro: Bertrand Brasil, 2006. 336p.

CORRÊA, R. L. As pequenas cidades na confluência do urbano e do rural. GEOUSP, São Paulo, n.30, 2011.

CROCETTI, Z. S. Formação Sócio-Espacial do Paraná. 2012. 355f. Tese (Doutorado em Geografia). Programa de Pós-Graduação em Geografia UFSC, 2012.

DEFFONTAINES, P. Como se constituiu no Brasil a Rede das Cidades. Boletim Geográfico, v.2, n. 14, p. 141-148, maio, 1944.

DEFFONTAINES, P. Como se constituiu no Brasil a Rede das Cidades II. Boletim Geográfico, v.2, n. 15, p. 299-308, maio, 1945.

FLORES, E. L. Industrialização e desenvolvimento no Sudoeste do Paraná. 2009. 226f. Dissertação (Mestrado em Geografia). UNIOESTE - Francisco Beltrão.

FRESCA, T. M. A dinâmica funcional da rede urbana do oeste paulista. 1990. 281f. Dissertação (Mestrado em Geografia) PPGG, UFSC, Florianópolis.

FRESCA, T. M. Transformações da rede urbana do Norte do Paraná. 2000. Tese. (Doutorado em Geografia Humana) Faculdade de Filosofia, Letras e Ciências Humanas, Universidade de São Paulo, São Paulo. GEIGER, P. P. Evolução da rede urbana brasileira. Rio de Janeiro: Centro Bras. de Pesq. Educ., 1963.

IBGE, Inst. Bras. de Geog. e Estat. Censo demográfico - Paraná - 1960. Rio de Janeiro: IBGE, 1960. v. 1. Tomo 14.

IBGE, Inst. Bras. de Geog. e Estat. Esboço preliminar de divisão do Brasil em espaços homogêneos e espaços polarizados. Rio de Janeiro, 1967.

IBGE, Inst. Bras. de Geog. e Estat. Subsídios à Regionalização. Rio de Janeiro: 1968.

IBGE, Inst. Bras. de Geog. e Estat. Censo demográfico - 1970. Rio de Janeiro: IBGE, 1970.

IBGE, Inst. Bras. de Geog. e Estat. Divisão do Brasil em regiões funcionais urbanas. Rio de Janeiro, 1972. 110p.

IBGE, Inst. Bras. de Geog. e Estat. Censo demográfico - 1980. Rio de Janeiro: IBGE, 1980.

IBGE, Inst. Bras. de Geog. e Estat. Regiões de influência das cidades brasileiras. Rio de Janeiro, 1987.

IBGE, Inst. Bras. de Geog. e Estat. Divisão do Brasil em mesorregiões e microrregiões geográficas. Rio de Janeiro: IBGE, 1990.

IBGE, Inst. Bras. de Geog. e Estat. Censo demográfico - Paraná - 1991. Rio de Janeiro: IBGE, 1991.

IBGE, Inst. Bras. de Geog. e Estat. Censo demográfico - Paraná - 2000. Rio de Janeiro: IBGE, 2000.

IBGE, Inst. Bras. de Geog. e Estat. Regiões de influência das cidades 1993. Rio de Janeiro: IBGE, 2000b. 230p. Disponível em <http://biblioteca.ibge.gov.br>. Acesso em 28/03/2007.

IBGE, Inst. Bras. de Geog. e Estat. Regiões de influência das cidades 2007. Rio de Janeiro: IBGE, 2008. 201p. Disponível em <http://www.ibge.gov.br/home/geociencias/geografia/regic.shtm>. Acesso em 12/10/2008. IPARDES; IPEA. Configuração atual e tendências da rede urbana do Brasil. Brasília: IPEA, 2002.

LAZIER, H. Análise histórica da posse da terra no sudoeste paranaense. Francisco Beltrão: Grafit, 1997. LÊNIN, V. I. O desenvolvimento do capitalismo na Rússia. São Paulo: 1982.402 p.

MAACK, R. Geografia física do estado do Paraná. Curitiba, PR: Imprensa Oficial do PR, 2002. 
MAMIGONIAN, A. Notas sobre o processo de industrialização no Brasil. Boletim do Departamento de Geografia, Presidente Prudente, n.2, p.55-63, 1969.

MAMIGONIAN, A. Notas sobre a geografia urbana brasileira. In: SANTOS, Milton (Org.) Novos rumos para a geografia brasileira. São Paulo: Hucitec, 1988, p.203-208.

MAMIGONIAN, A. A Geografia e "A Formação Social como Teoria e como Método". In: SOUZA, Maria Adélia A. de. (Org.) Mundo do cidadão, um cidadão do mundo. São Paulo: Hucitec, 1996, p.198-206.

MANDEL. E. Introdução ao marxismo. Porto Alegre: Movimento, 1982.

MARTINS, R. S. Entre jagunços e posseiros. Francisco Beltrão: Edição do autor, 1986.

MARX, K. O capital. São Paulo: Abril Cultural, 1983. v. 1. (Os economistas).

MARX, K.; ENGELS, F. A ideologia alemã. São Paulo: Martins Fontes, 1998.

MONBEIG, P. O estudo geográfico das cidades. Boletim Geográfico, a.1, n. 7, p. 7-29, 1943.

MONBEIG, P. Pionners et Planteurs de São Paulo. Paris: Librairie Armand Colin, 1952.

MONBEIG, P. Resumo da Geografia Econômica do café. Boletim Geográfico, a.12, n. 122, p.276-287, set./out., 1954.

MÜLLER, N. L. Evolução e estado atual dos estudos de geografia urbana no Brasil. Boletim Geográfico, Rio de Janeiro, n. 209, p. 28-64, mar./abr. 1969.

OLIVEIRA, D. de. Urbanização e industrialização no Paraná. Curitiba: SEED, 2001. 113p.

RANGEL, I. Introdução ao desenvolvimento econômico brasileiro. Rio de Janeiro: Bienal, 1990. 125p.

ROCHEFORT M. Métodos de estudos das redes urbanas: interesse da análise e do setor terciário da população ativa. Boletim Geográfico, a. 19, n. 160, p. 3-19, jan./fev., 1961.

SANTOS, M. Sociedade e Espaço: A Formação Social como Teoria e como Método. Boletim Paulista de Geografia, São Paulo, n.54, p.81-100, jun. 1977.

SANTOS, M. O espaço dividido. Rio de Janeiro: F. Alves, 1979.

SANTOS, M. Espaço e método. São Paulo: Nobel, 1985.

SANTOS, M. A urbanização brasileira. São Paulo: Hucitec, 1993.

VOLTOLINI, S. Retorno 3: ciclo da madeira em Pato Branco. Pato Branco, PR: Imprepel, 2000. 